\title{
IDENTIFICATION AND TYPOLOGY OF CZECH POST- INDUSTRIAL LANDSCAPES ON NATIONAL LEVEL USING GIS AND PUBLICLY ACCESSED GEODATABASES
}

\author{
JAROMÍR KOLEJKA, MARTIN KLIMÁNEK
}

Institute of Geonics, Academy of Sciences of Czech Republic, Studentska 1768, 70800 Ostrava-Poruba, Brno Branch, Department of Environmental Geography, Drobného 28, 61300 Brno, Czech Republic; e-mail: kolejka@ geonika.cz

Mendel University, Faculty of Forestry and Wood Technology, Department of Geoinformation Technology, Zemědělská 3, 61300 Brno, Czech Republic; e-mail: klimanek@mendelu.cz

\begin{abstract}
Kolejka J., Klimánek M.: Identification and typology of Czech post-industrial landscapes on national level using GIS and publicly accessed geodatabases. Ekológia (Bratislava), Vol. 34, No. 2, p. $121-136,2015$

The post-industrial landscape (PIL) is a generally accepted phenomenon of the present world. Its features are fossil in comparison to those ones in operating industrial landscapes. The required knowledge about the position, size, shape and type of PIL will help decision makers plan PIL future. The paper deals with the selection of identification features of PILs. Applicable data must be related to four landscape structures: natural, economic (land use), social (human) and spiritual. Present Czech geodatabases contain sufficient quantity and quality of data they can be interpreted as source of PIL identification criteria. GIS technology was applied for such data collection, geometric and format pre-processing, thematic reclassification and final processing. Using selected identification and classification criteria, 105 PILs were identified on the Territory of Czech Republic and classified into individual types. A SWOT analysis of results was carried out to identify the reliability level of data and the data processing. The identified PILs represent the primary results generally obtained in the Czech Republic. GIS approach allows repeated procedures elsewhere in EU member states because of some similarity of available geodatabases. Of course, an improvement of classification procedure depends on the real situation in each country.
\end{abstract}

Key words: industrial heritage, landscapes, mapping, classification.

\section{Introduction}

The Industrial Revolution, which began approximately in the mid-18th century in the United Kingdom, reached the Czech lands (the Kingdom of Bohemia, Markgraviate of Moravia and the Duchy of Silesia) constituting a part of the multi-national Hapsburg Monarchy in the late 18th century (particularly ensuing the abolition of serfdom in 1781). However, crucial changes in the landscape relating to the development of industrial production did not arrive until the mid-19th century and were conditioned by changes in the Monarchy's social and economic conditions (emancipation of peasants in 1848) as well as by the development 
of modern transport particularly railroads and technological progress. The second half of the 19th century was marked by a sudden increase in newly established industrial companies throughout the Czech regions. The geographic distribution of industries and individual companies respected natural localisation factors (energy sources-fossil fuels, watercourses, raw material sources-ores, plants, timber, glass sands, and silica), social (workforce, qualified workers) as well as economic factors (market-supply and demand, access to market-advantageous transport links, initially in the form of navigable rivers and later as railroads and to a much lesser extent, roads). The first wave of Czech industrialisation culminated between 1870 and 1914 and gave rise to poly-functional and specialised industrial regions where industrial activities had a major impact on the landscape appearance as well as qualitative changes in individual components of the natural, social and economic environments. While changes in the natural environment (relief, geological environment, top climate, waters, soils, and biota) were far from positive as opposed to today's perspective, changes in economic and social spheres led to an unprecedented increase in general standard of living compared to past times, regardless of enhanced social differences. Thousands of industrial companies emerged throughout Czech lands, not only in cities and towns but also frequently in completely rural agricultural and dense forest areas. Already back then, periodic economic crises precipitated the closings of inefficient businesses which due to their outdated technology were unable to compete with more progressive and flexible companies. Metallurgy in particular underwent radical changes related to increased use of coal and coke due to advances in smelting technology (which enabled extraction of metals even from ores of inferior quality). Inorganic chemistry was subject to similar radical changes as well. The textile industry shifted focus from domestic materials to imported ones (wool, cotton) while engineering industry started to increasingly produce electric equipment at the expense of steam engines. Even then, outdated industries (especially inland) left behind obsolete industrial zones which hailed the arrival of post-industrial landscapes over a century later due to radical economic restructuring in developed countries.

The interwar period was marked by the disintegration of the immense Austro-Hungarian domestic market, by the Great Depression after 1928, by political tension felt after 1933 as well as by the emergence of a modern global market. This led to further consolidation of the engineering industry (automotive production and manufacturing), power engineering, industrial organic chemistry and petro chemistry, building material production for state-of-the-art constructions as well as massive consumer goods productions (household appliances, footwear, furniture, paper or toys). The newly established businesses were built from scratch either in the vicinity of traditional industrial areas or in the newly isindustrialised regions (in the east of today's Czech Republic) and a certain degree of state control was exercised particularly in the sphere of arms industry and related productions. This period was marked by the closing down of obsolete coal mining plants, a number of textile factories, glassworks, sugar refineries and some engineering plants (particularly in regions along the border). Railway networks saw their heydays in terms of density and length of railways. There were major developments where road network was improved by paving in its key sections, construction of motorway network was launched and new segments of water channels were built. 
The Czech lands were not deeply affected by the destruction caused due to World War II. However, particularly the heavy industrial factories suffered substantial damage. Remediation of this damage was launched shortly after the end of war operations in the late 1940s. In the 1950s it was followed by massive development in the newly nationalised heavy industry, particularly in ferrous metallurgy, heavy engineering (including extensive arms production), chemical production and coal power engineering (partly built from scratch) which was indispensable for the Czech economy characterised by high energy and raw material consumption. The strictly centralised economy marginalised numerous businesses producing consumer goods, whose shortages became symptomatic of the economy's long-term conceptual planning. It was not until the second half of the 1960s when consumer goods production increased and high-ranking political officials could no longer explain the shortages by threats directed at the Czech economy by western democracies. Yet, demand for consumer goods still failed to be met. The 1970s saw a certain degree of modernisation, particularly in the automotive, electrical, chemical and some engineering industries. The turn of the 1960s and 1970s was also characterised by massive construction of facilities designed for Soviet army garrisons, which factually sustained the time-unlimited status of Soviet troops' presence in the Czech territory following the invasion of 1968. It was not until the second half of the 1980s when computer-controlled production, automation, robotisation and a more responsible approach to the environment could be detected, although it was slower and to a significantly lesser degree than in other industrially developed countries. This period also saw the implementation of fundamental changes in agriculture which were characterised by a shift towards concentration and industrialisation. While vast livestock production facilities, storage spaces and intensive large-scale plant production facilities sprang up in many places, staggering numbers of smaller farming facilities were abandoned.

The economic, social and political changes in the 1990s were to a substantial degree associated with the non-transparent privatisation of state companies, farmland and partly also forests which resulted in the collapse of numerous businesses, not only the inefficient ones. More importantly, energy and material intensive production was abandoned, arms production slumped as a result of political motivation, various big agricultural companies disintegrated due to limited financial state support which until then had been intended to maintain equal efficiency of companies operating in differing conditions and both the Czech society and landscape were demilitarised thanks to the withdrawal of Soviet troops and a radical staff cuts in the Czech army which became professional. Added to these factors, cheap competition from abroad combined with failed privatisation virtually eliminated the still flourishing businesses in textile, glass, heavy and light electrical industries as well as truck or rail vehicle production. Due to this the numbers and area of derelict production facilities and urbanised areas-brownfields-skyrocketed. At present, the area of officially registered brownfields in the Czech Republic covers 12,000 ha (Regnerová, 2006). Yet, apart from brownfields, the industrial landscape is characterised by a number of other parameters.

\section{Present Level of Post-Industrial Landscape Studies}

Post-industrial landscape is a legacy of the Industrial Revolution. Its origins date back to the industrial period when industrial and accompanying activities and facilities imprinted themselves 
into the landscape's character, its structure and functions. After industrial activities had left the landscape, a number of "fossil" traces of such activities in the form of buildings, changes in relief, water management facilities, chemical contaminations and socio-economic impacts remained in it. According to Ling et al. (2007) post-industrial landscapes are understood as areas significantly affected by mining, with a number of abandoned objects and brownfields, which can be subject to new regeneration programs that provide opportunities for re-development. The post-industrial landscapes or industrial heritage draw the attention of the general public and experts alike because of the architectural value of individual buildings as well as entire industrial areas. These have become particularly appreciated in recent years. Owing to the fact that a number of valuable industrial buildings ceased to fulfil their original purpose, they faced the grim prospects of demolition or alteration which would efface their character and singularity. Starting with the 1970s, a number of countries have opted for various forms of industrial area redevelopment and transformed them into shopping, leisure or residential facilities. However, the numbers of industrial heritage buildings and areas in danger of extinction remain vast. Various countries have conducted industrial heritage inventory, e.g. in England (http://industrious.icserver26.de/index.php? pageId=1), Scotland (http://www. sihs.co.uk/index.htm), Irsko (http://www.industrialheritage ireland.info/), Canada (http:// www.canadianindustrialheritage.org/index.html), Latvia (http://www.i-mantojums.lv/eng /frames/sakumlapa.htm), Czechia (http://www. brownfieldy.cz), including regions in the USA, Germany, the Netherlands, Japan, and other countries. A number of mostly non-governmental organisations, both national and international, among them the Research Centre for Industrial Heritage of the Czech Technical University in Prague, Cuffley Industrial Heritage Society-England, The Scottish Industrial Heritage Society, Association for Industrial Archaeology, Canadian Industrial Heritage Centre, The Industrial Heritage Archives of Chicago's Calumet Region, The International Committee for the Conservation of the Industrial Heritage, European Route of Industrial Heritage (ERIH) and some others. Focus on inventory and protection of industrial heritage is visible in developed countries. The significance of industrial heritage for the contemporary society was acknowledged in the publication of the Nizhny Tagil Charter for the Industrial Heritage in 2003 (Loures, 2008).

The issue of industrial heritage is studied from the archaeological perspective (Romania, see Hillinger et al., 2001), as well as from the ecological one (in the 1970s and 1980s, the Institute of Ecology of Industrial Landscape of the Czechoslovak Academy of Sciences was active in Ostrava). When compared to the unmistakable interest in industrial architecture, relatively less attention is paid to the environment where such architecture is set, i.e. to the landscape. Living industrial landscape has found its place in landscape studies (see e.g. Hladnik, 2005; Gospodini, 2006; Vráblíková, Vráblík, 2007). The Munich University of Technology even established a Chair of Landscape Architecture and Industrial Landscape. It is worth mentioning that landscape study findings have found their practical application in the urbanised landscapes of western European and North American cities (London, Manchester, Glagow, Hamburg, Vienna, Boston, Pittsburghu, etc.) as well as in Japan and New Zealand (Hall, 1997; Whitehand, Morton, 2004; Loures, 2008).

The wider "rural" industrial space (see Hayes, 2006; Kolejka, 2006) tends to be characteristic of areas affected by underground or surface extraction of coal as well as some ores, phos- 
phates and building materials and the associated industrial energy and metallurgy establishments (Ruhrland, Lorraine, Lower Lusatia, Upper Silesia, Ore Mts. Piedmont in Czechia, Pennsylvania). Parts of such "rural" and most "urban" industrial landscapes (Hüttl, 1998; Sklenicka, Charvatova, 2003; Slámová, 2006; Vráblíková, Vráblík, 2007; Conesa et al., 2008; Dulias, 2010) have undergone the stage of spontaneous transformation into post-industrial landscapes after the local industrial production collapsed and the original industrial areas were abandoned or transformed. The expert community studying the post-industrial landscape traditionally focuses on its architectural (Cashen, 2007), economic (Shahid, Nabeshima, 2005; Dunham-Jones, 2007), social (Kirkwood, 2001; Kirk, 2003; Hansen, Winther, 2006) and biological or environmental aspects, particularly in relation to the occurrence of biotic communities and species, as well as soil and water remediation (Kirkwood, 2001; Keil, 2005).

Coordinated efforts of state, NGOs and private organisations have led to targeted transformation of extended areas into contemporary post-industrial landscapes. Examples of such efforts can be seen in larger areas in Ruhrgebiet (Emscher-Park - Fragner, 2005), Wales (vicinity of the town of Blaenavon as UNESCO WHS-Rogers, 2006), England (Dearne Valley in South Yorkshire-Ling et al., 2007), Portugal (Loures, 2008) or Germany (the Regen River Valley).

The spatial aspects, definition, classification and typology of the industrial landscape only exceptionally become the focus of research. Stuczynski et al. (2009) drew on an original concept in the course of geographic definition of post-industrial regions in EU. They drew on CORINE LC 2000 database which registers industrial, mining and waste disposal sites. Based on specific assessment of the database content, as well as calculations in $5 \times 5 \mathrm{~km}$ square grid and other hypotheses and socio-economic data the team classified the NUTS-3 EU-27units into six types according to their post-industrial character. The authors focused primarily on detailed description of individual studied areas, as it was required for their conservation and further development planning. Examples attest to the fact that the protection of such areas was timely. The knowledge of delimitation of such areas (location, surface area, shape of the site and its borders) and the occurrence of different types of post-industrial landscapes represent the primary condition for state administration bodies, planning and conservation organisations and developers to adopt their respective viewpoints. The general public and media require the same information as well. The prerequisite for the post-industrial landscape's future planning is the most accurate definition, localisation and description, which serve as point of departure for ensuing classifications. Individual types of post-industrial landscape then can be to a certain degree related to standard restoration, development and possibly also conservation acts.

\section{Features of Post-Industrial Landscape}

The post-industrial landscape is a historical continuation of the industrial landscape (Kučerjavij, 1999; Kolejka, 2006). While all definition characteristics of the industrial landscape are active and recent, they become "dead" and fossil in the post-industrial landscape. Generally speaking, this point of departure is relevant to all structures of the contemporary 
cultural landscape: natural-represented by the spatial distribution of homogenous landscape units-geosystems, characterised by natural combinations of rock, relief, atmosphere (climate), water bodies (and humidity relations), soil and biota characteristics;

economic-represented by a mosaic of land cover either used or not used by humans-e.g. forests, water bodies, meadows and pastures, arable land, permanent crops, various forms of development etc.;

human-represented by spatial projections of varying interests, restrictions and stimuli (frequently overlapping) which can be related to legislative measures (protected natural ar-

T a b l e 1. Post-Industrial Landscape and Its Basic Features.

\begin{tabular}{|c|c|c|c|c|c|}
\hline No. & Data source & Source administrator & Selected characteristics & $\begin{array}{l}\text { Relation to industrial } \\
\text { heritage }\end{array}$ & Implementation \\
\hline 1 & \begin{tabular}{|l|} 
ZABAGED \\
- basic set of \\
geographic \\
data
\end{tabular} & $\begin{array}{l}\text { Czech Office for } \\
\text { Surveying, Mapping } \\
\text { and Cadastre }\end{array}$ & $\begin{array}{l}\text { Scale 1:10 000, } \\
\text { polygons, geographic } \\
\text { coordinates of shapes in } \\
\text { the S-JTSK coordinate } \\
\text { system }\end{array}$ & $\begin{array}{l}\text { mining sites, industrial } \\
\text { sites, waste deposits, } \\
\text { mine dumps }\end{array}$ & $\begin{array}{l}\text { upon concluded } \\
\text { generalization it is } \\
\text { necessary to separate } \\
\text { post-industrial sites } \\
\text { and construct a buffer } \\
\text { around polygon }\end{array}$ \\
\hline 2 & $\begin{array}{l}\text { CORINE } \\
\text { Land Cover } \\
2006\end{array}$ & $\begin{array}{l}\text { Ministry of } \\
\text { Environment of the } \\
\text { Czech Republic }\end{array}$ & $\begin{array}{l}\text { Scale } 1: 50000, \\
\text { polygons, WGS } 84 \\
\text { coordinate system, min. } \\
\text { area } 25 \text { ha }\end{array}$ & $\begin{array}{l}\text { industrial and } \\
\text { commercial areas-class } \\
121, \text { mining sites-131, } \\
\text { waste deposits-132 }\end{array}$ & $\begin{array}{l}\text { good, post-industrial } \\
\text { sites must be separated, } \\
\text { buffer constructed for } \\
\text { polygon }\end{array}$ \\
\hline 3 & $\begin{array}{l}\text { National } \\
\text { inventory } \\
\text { of contami- } \\
\text { nated sites }\end{array}$ & $\begin{array}{l}\text { CEN } \\
\text { orgar }\end{array}$ & $\begin{array}{l}\text { localization of gravity } \\
\text { points according to } \\
\text { coordinates obtained } \\
\text { in field through GPS } \\
\text { technology, points, } \\
\text { S-JTSK }\end{array}$ & $\begin{array}{l}\text { chemical } \\
\text { contaminations }\end{array}$ & $\begin{array}{l}\text { buffers constructed for } \\
\text { points }\end{array}$ \\
\hline 4 & $\begin{array}{l}\text { Czech } \\
\text { brownfields } \\
\text { catalogue }\end{array}$ & $\begin{array}{l}\text { vest-state } \\
\text { tion }\end{array}$ & $\begin{array}{l}\text { scale approx. 1:10 000, } \\
\text { points, localization of } \\
\text { gravity points in the } \\
\text { S-42 coordinate system }\end{array}$ & $\begin{array}{l}\text { brownfields according } \\
\text { to their original use, } \\
\text { localized to settlements }\end{array}$ & $\begin{array}{l}\text { buffers constructed for } \\
\text { points }\end{array}$ \\
\hline 5 & $\begin{array}{l}\text { mining } \\
\text { subsidence } \\
\text { areas (points } \\
\text { and sites) }\end{array}$ & $\begin{array}{l}\text { Czech Geological } \\
\text { Survey }\end{array}$ & $\begin{array}{l}\text { scale approx. 1:50 000, } \\
\text { polygons (min. area } \\
4 \mathrm{~km} 2 \text { ) and points } \\
\text { (gravity points of } \\
\text { areas less than } 4 \mathrm{~km} 2 \text { ), } \\
\text { S-JTSK coordinate } \\
\text { system, }\end{array}$ & subsidence & $\begin{array}{l}\text { good in sites exceeding } \\
4 \mathrm{~km} 2 \text {, extract from } \\
\text { the mining subsidence } \\
\text { areas, polygons with } \\
\text { constructed buffers }\end{array}$ \\
\hline 6 & $\begin{array}{l}\text { urban areas } \\
\text { of over } \\
50000 \\
\text { inhabitants }\end{array}$ & $\begin{array}{l}\text { ARCDATA PRAHA, } \\
\text { Ltd., commercial set } \\
\text { ARC CR 500, incl. } \\
\text { own interpretations of } \\
\text { aerial photographs on } \\
\text { CENIA website }\end{array}$ & $\begin{array}{l}\text { scale 1:100 000, built- } \\
\text { up areas of residential, } \\
\text { production and service } \\
\text { character, coordinates } \\
\text { in S-42 system }\end{array}$ & $\begin{array}{l}\text { representing a mix } \\
\text { of industrial and } \\
\text { post-industrial objects } \\
\text { within dominant urban } \\
\text { landscape }\end{array}$ & $\begin{array}{l}\text { utilizable as a mask for } \\
\text { filtering areas whose } \\
\text { landscape character } \\
\text { is defined by the } \\
\text { metropolis and not the } \\
\text { industrial heritage }\end{array}$ \\
\hline 7 & district towns & $\begin{array}{l}\text { Czech Statistical } \\
\text { Office }\end{array}$ & $\begin{array}{l}\text { scale 1:10 000, cadastral } \\
\text { areas of district towns, } \\
\text { coordinates in the } \\
\text { S-JTSK system }\end{array}$ & $\begin{array}{l}\text { enables separation } \\
\text { of the towns' urban } \\
\text { landscape from the } \\
\text { remaining area }\end{array}$ & $\begin{array}{l}\text { delimitation of district } \\
\text { town areas according } \\
\text { to a code in attribute } \\
\text { table }\end{array}$ \\
\hline
\end{tabular}


eas, cultural monuments or technical infrastructure) and to individual, collective, general, state or even international interests (development, investment, defensive and other). These stakeholder interests are markedly modified by population density, religious, national, social and other types of structures, culture, education, traditions, etc.;

spiritual-related to the spatially differentiated positive or negative perception of the landscape which is best represented by the "genius loci" of certain sites. The positive or negative perception of given sites within the landscape then significantly affects the distribution of stakeholder interests in it and consequently determines the distribution of used (or neglected) areas.

Although the list of definitions cannot be complete, the basic features may be ascribed to phenomena within individual landscape structures (Table 1). However, this does not necessarily mean that every post-industrial landscape must contain a complete set of the features listed below. Relative to the given post-industrial landscape type, it will be characterised by a specific partial selection of characteristic parameters.

As a rule, landscape scientists will tend to face the real-life issue of identification, mapping, classification and typology of post-industrial landscape areas based on insufficient bulk of relevant geo-data. Such situations will require undertaking the above-listed operations with full knowledge of a certain degree of inaccuracy in the obtained results, which may be subject to discussion but also provide a convincing justification. The following demonstration of methods of identification and typology of post-industrial landscapes at the Czech Republic national level may serve as an example. Owing to the fact that it draws on data analogous in many other EU and foreign countries, such demonstration may be applicable in their territory upon obtaining similar results.

\section{Material and methods of Post-Industrial Landscape Identification at a National Level}

The existence of post-industrial landscapes is a generally acknowledged fact, as examples from books and journals demonstrate together with conservation and state administration bodies which have expressed interest in specifying of the term "post-industrial landscape" in the Czech Republic, as well as criteria set to define this type of contemporary cultural landscape. While a number of general defining characteristics of such landscapes can be found easily (see Table 1), the actual coverage of such characteristics by existing and available geodata is significantly poorer.

The following demonstration of identifying individual areas of the post-industrial landscape draws both factually and methodology-wise on relevant spatial data available for the entire Czech Republic. Needless to say that a sufficient amount of data sets to cover all the aspects of the post-industrial landscape is not available and presumably will not be available in the foreseeable future. All EU countries are probably facing similar challenges, but since the data used in the following process of post-industrial landscape identification and mapping (Table 2) are created and recorded in many other countries, a similar procedure with the same objective may be repeated outside the Czech Republic as well.

The actual process of defining PIL in the Czech Republic can be divided into the following steps:

Step 1: Conversion of all data layers into the S- 42 coordinate system. This is associated with forming a unified GIS geo-database which encompasses data layers for all used variables. Although the implemented GIS SW ESRI ArcGIS 9.2 supports parallel processing of data layers in various formats and projections, all data layers were converted into shape file format for practical reasons.

Step 2: Construction of polygon layers from point layers related to old chemical burdens (contaminated sites-variable 1, Fig. 1), brownfields (variable 2) and small-scale undermined sites (variable 3). Conversion from point to polygon layer is essential to obtain area output and minimises the subjective and non-homogenous assessment of point concentrations localising sites with old chemical contaminations (Fig. 2). Determination of the buffer zone diameter may also prove arguable. Experiments with several options resulted in setting the buffer size at $500 \mathrm{~m}$. Its practi- 


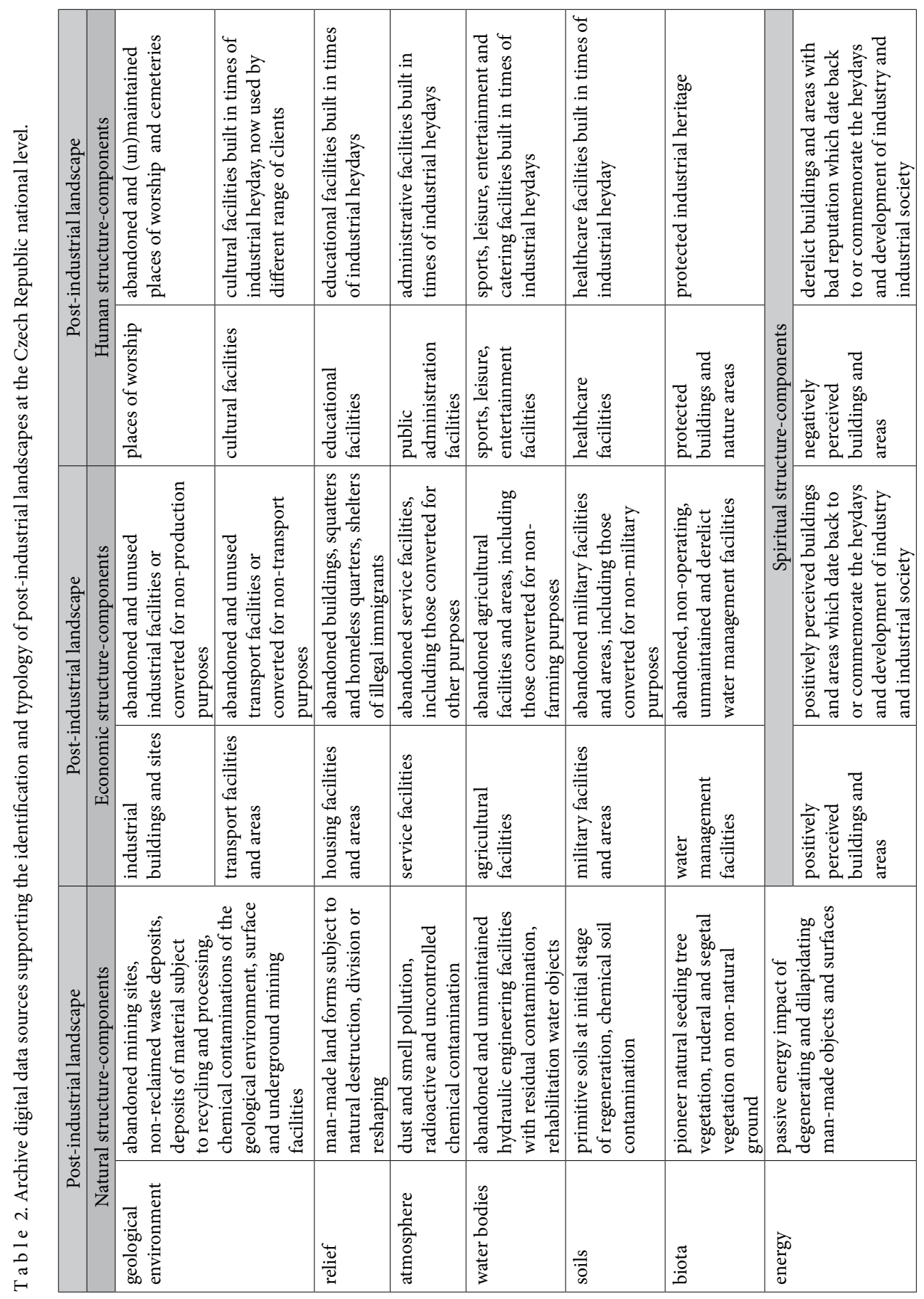


cal advantage is that the circle around a central point has $1 \mathrm{~km}$ diameter. The distance between two neighbouring points of old chemical contaminations, brownfields and mining subsidence sites which may constitute a single polygon is then a maximum of $1 \mathrm{~km}$ (in an extreme case, the buffers touch each other in a single point).

The $500 \mathrm{~m}$ distance from a source of pollution may also be conventionally considered the range of the source's impact, although the factors of soil, rock and hydrogeological environments may distort its impact range significantly. The extraction of brownfield polygon layers from point layers displays the same shortcomings (brownfields being localised according to the geographical coordinates of their areas' gravity points or address points). The primary objective of this step is to transform the point layer to a polygon one while demonstrating a certain hypothetical areal visual (aesthetic) or perceptive impact (positive or negative perception of the given object in its "neighbourhood"). In this case the $500 \mathrm{~m}$ buffer zone meets the above mentioned requirements. Objects of this kind are not generally considered intrusive provided they are located at a minimum distance of $500 \mathrm{~m}$, as their immediate negative visual perception ceases to be felt at this distance.

The procedure of polygon layer construction from point layer of small-scale mining subsidence sites is analogous. The purpose of this step is identical with the preceding ones. A $500 \mathrm{~m}$ buffer was implemented in this case as well. The point data lack (apart from GPS localisation of their gravity points) the exact knowledge of the mining subsidence area extent which may oscillate between a single point and $4 \mathrm{~km}^{2}$. Constructing buffers around these points therefore represents only a certain compromise between the site knowledge and its mere point localisation.

Step 3: Formation of analogous buffer zones along the outer edges of areaspolygons of large-scale undermined sites (over $4 \mathrm{~km}^{2}$-variable 5, Fig. 3), mine dumps and waste deposits (varia-

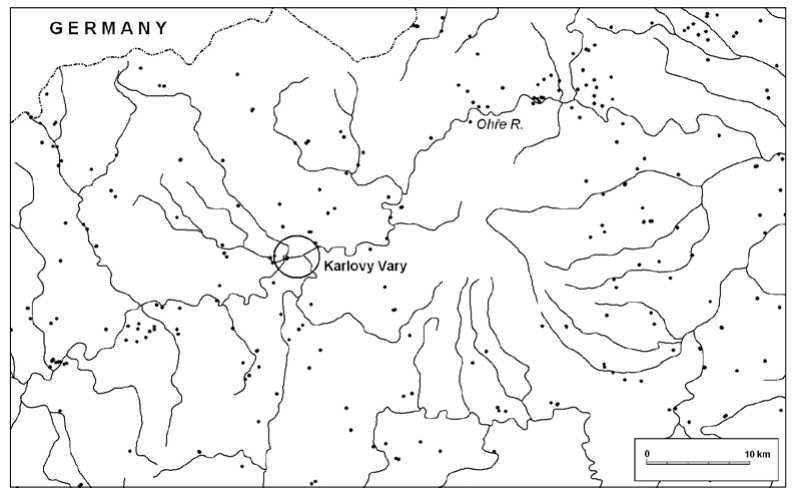

Fig. 1. Point data example - contaminated sites in Western Bohemia, Czech Republic. Source: Cenia

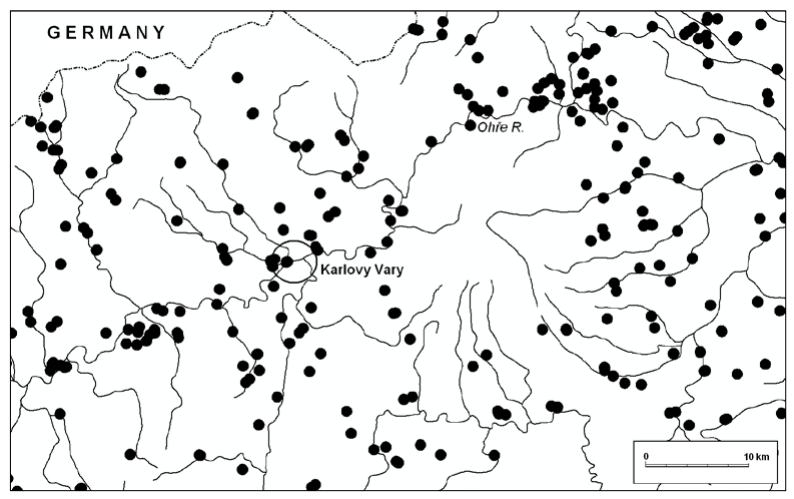

Fig. 2. Preliminary data pre-processing - contaminated sites with 500 $\mathrm{m}$ buffers in Western Bohemia, Czech Republic. Source: Cenia

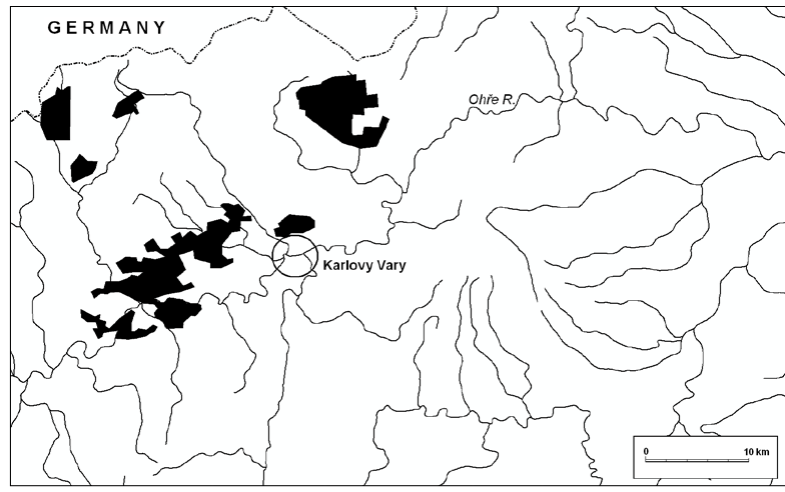

Fig. 3. Polygon data example - undermined areas in Western Bohemia, Czech Republic. Original source: Czech Geological Survey 


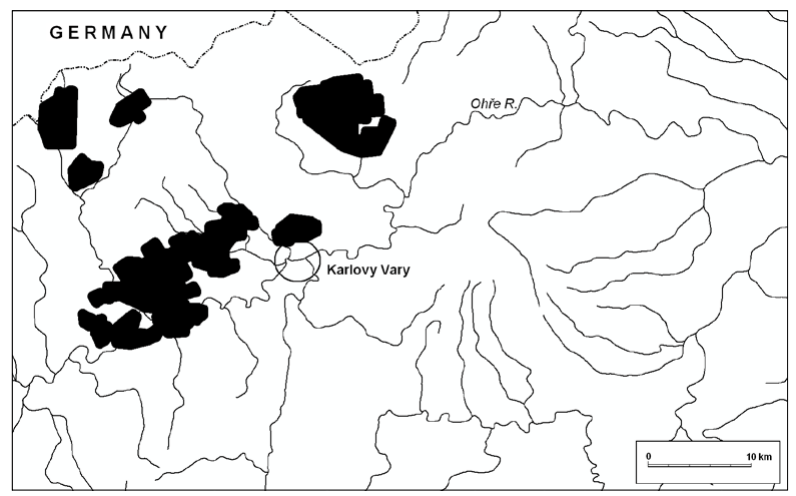

Fig. 4. Preliminary data pre-processing - undermined areas with 500 $\mathrm{m}$ buffers in Western Bohemia, Czech Republic. Original source: Czech Geological Survey

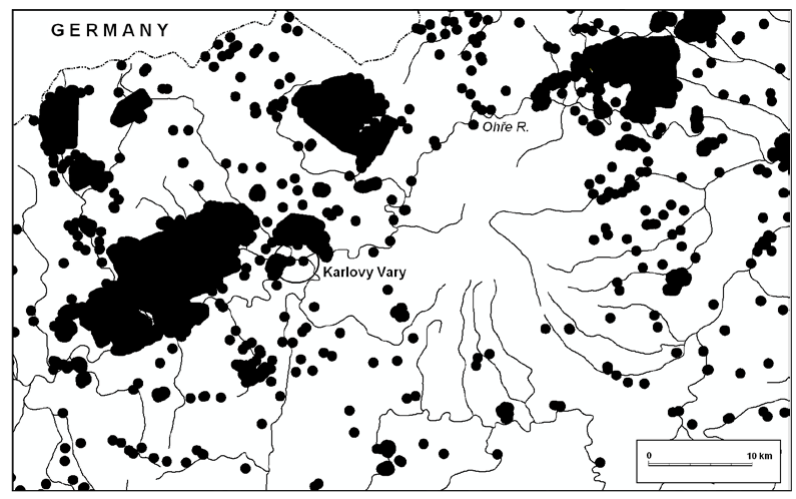

Fig. 5. Cartographic presentation of all pre-processed data layers with buffers in Western Bohemia, Czech Republic. Original source: Cenia, Czech Geological Survey, Czechinvest, Czech Office for Surveying, Mapping and Cadastre, Ministry of the Environment of the Czech Republic, CORINE LC

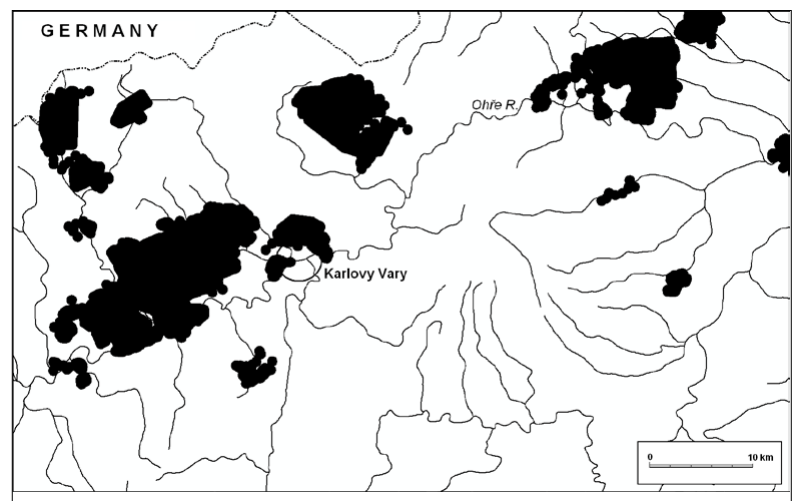

Fig. 6. Joint polygons of post-industrial landscape indicators into areas larger than $5 \mathrm{sq} \mathrm{km}$ in Western Bohemia, Czech Republic. ble 5) or industrial sites with brownfields (variable 6), as well as mining land forms (variable 7). Other types of industrial sites without brownfields, or without contact with these, were excluded from the processing. The $500 \mathrm{~m}$ buffer width symbolises similar direct factual and visual impact of these objects (Fig. 4). Although this approach significantly overestimates the area particularly of small objects, it must be taken into consideration that their environmental impact does not end abruptly at their borders. The adopted buffer width represents a compromise between the available data and the actual impact of all types of objects and the virtually absolute lack of data on the specific situation in their vicinity.

Step 4: Integration of polygon layers of buffers along old chemical contamination sites and brownfields with areas of other polygons equipped with buffers of the same widths along their outer borders. This step allows to combine and connect (in individual cases and if possible) all seven existing variables into heterogeneous areas (Fig. 5). It is apparent that the number of registered old chemical contaminations (contaminated sites) in the used database (7,930 cases), significantly exceeds the number of registered brownfields (841) as well as the numbers of other variable polygons (waste deposits and mining dumps-254, industrial areas-901, large-scale mining areas (over $4 \mathrm{~km}^{2}$ )-48, small-scale mining sites-1,298). By spatial aggregation of buffers along points and polygons we may obtain polygons consisting of a minimum of two buffer areas (any out of the seven types of point or area sites individually or any of their combinations, provided that they encompass a maximum of all seven types of areas with at least one representative of each type, except areas with buffers without contact with any of the other sites). Naturally, this step caters to a wide spectrum of various-sized areas. The area minimum is represented by the area of a single isolated buffer around a point object (approx. $0.8 \mathrm{~km}^{2}$ ). The upper threshold cannot be determined in advance. It arises from real-time results obtained through combinations of used 
analytical sites. The total number of determined areas of all sizes amounted to 5,757 .

Step 5: Preliminary elimination of smallscale areas representing mere potential cores of post-industrial landscape units. At the Czech Republic national level and upon implementing the lowest resolution level of used materials (mining areas), we may theoretically distinguish areas of a minimum of $4 \mathrm{~km}^{2}$. At the same time, the area of an isolated buffer around a point is approx. $0.8 \mathrm{~km}^{2}$, i.e. 80 ha. Landscape mapping using integrated data in scale 1:500 000 has a minimum resolution area of $5 \times 5 \mathrm{~mm}$, i.e. $2.5 \times 2.5 \mathrm{~km}$, which is 4.25 $\mathrm{km}^{2}$. Upon rounding up we can arrive at conventional determination of a minimum area of an individual post-industrial landscape unit covering $5 \mathrm{~km}^{2}$. Areas of less than $5 \mathrm{~km}^{2}$ may be considered post-industrial landscape cores termed "post-industrial areas", while sites of 5 $\mathrm{km}^{2}$ and more may be classified as "postindustrial landscapes" at the national resolution level. The above-mentioned areas of less than $5 \mathrm{~km}^{2}$ may be excluded from the processing (Fig. 6).

Step 6: Filtering urban areas of over 50,000 inhabitants as well as district town cadastres of all sizes. Towns of over 50,000 inhabitants may encompass large numbers of industrial heritage objects but their character is defined by contemporary activities, whether it is housing,

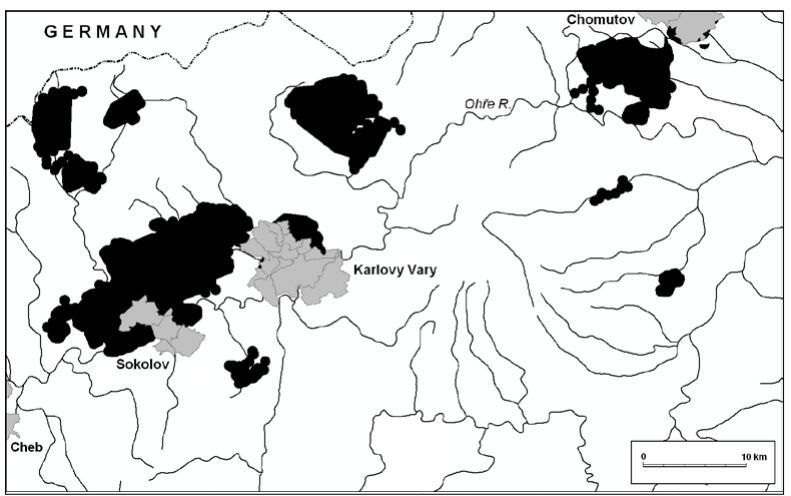

Fig. 7. Extraction of joint areas with post-industrial landscape indicators on territory of district capitals in Western Bohemia, Czech Republic.

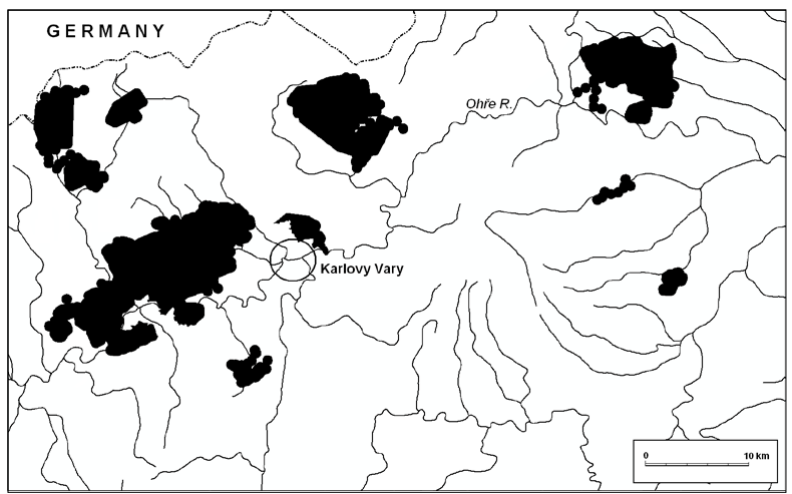

Fig. 8. Post-industrial landscapes larger than $5 \mathrm{sq} \mathrm{km}$ identified with dissected outlines in „rural areas“ of Western Bohemia, Czech Republic. modern and traditional industrial pro-

duction, services, arts, commercial and sports activities and related facilities. There may be significant concentrations of abandoned buildings and areas, but compared to "active" areas, these "fossil" ones are of lower significance and do not tend to form post-industrial landscapes. District towns, which are characterised by higher concentrations of recent residential, commercial and production activities, similarly exhibit insignificant concentration of industrial heritage compared with the former. Identification of "urban" post-industrial landscape may be possible upon higher resolution at the local or choric level. However, in this case the objective is to define "rural" post-industrial landscape at the nation level outside urban/metropolitan areas where industrial heritage plays an important physiognomic role (Fig. 7).

Step 7: Final elimination of residuals after filtering. Again the areas of less than $5 \mathrm{~km}^{2}$ may be excluded from the process of classification and typology (Fig. 8). Within the area of the Czech Republic a total of 105 examples of post-industrial landscapes (covering areas of over $5 \mathrm{~km}^{2}$ ) were identified and for comparison purposes 44 examples of post-industrial landscapes covering more than $10 \mathrm{~km}^{2}$ were selected.

Step 8: Classification of post-industrial landscape units. The principal classification criterion of the determined postindustrial areas is their genesis or the process of the given post-industrial landscape origin. It involves assigning a contemporary post-industrial landscape to activity/activities which played a crucial role in its/their genesis. Naturally, past dominant activities represent the major genetic factor, whether individual industrial sectors, military activities, housing or farming, mining or waste disposals. At the first stage of the classification it suffices to assign a given area to an activity which has affected the major part of the defined post-industrial landscape or, in the case of point data, an activity which is most frequently represented. An exception to this rule is areas defined by overlapping buffers around 


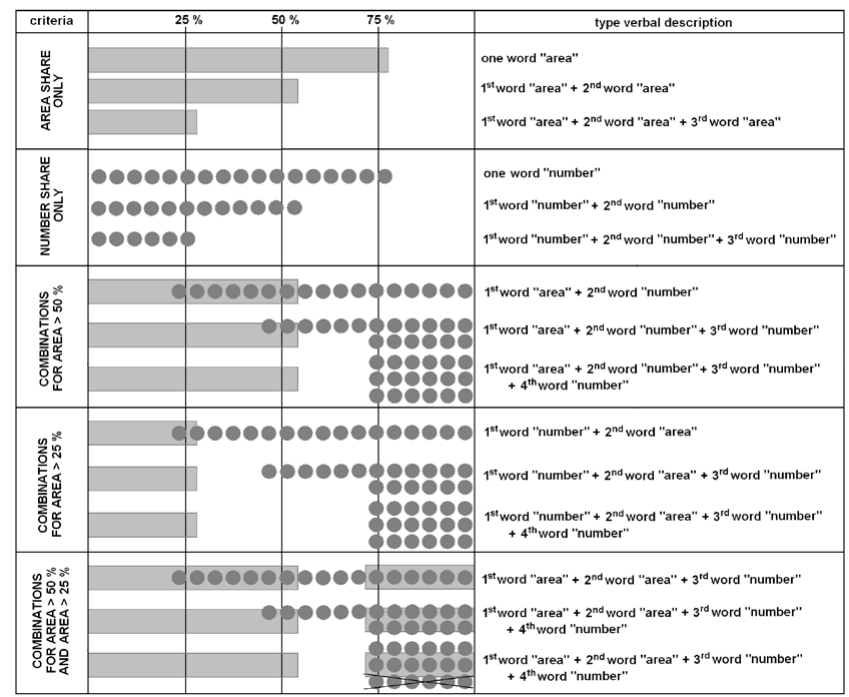

Fig. 9. Post-industrial landscape classification criteria and their application in landscape verbal description using from one to four words for dominant polygon, point or combined polygon-point indicators.

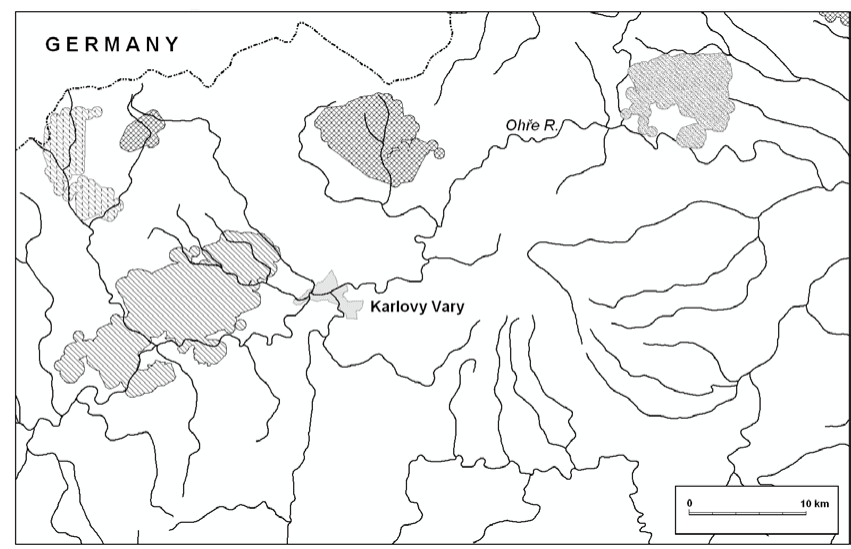

Fig. 10. Classified post-industrial landscapes identified with original dissected outlines in Western Bohemia, Czech Republic. old chemically contaminated sites. In this case the classification of thus delimited post-industrial landscape draws on any other activity dominant in the past (Fig. 9).

Step 9: Areas identified in the preceding steps frequently represent highly bizarre shapes with jagged edges, depending on which individual sites determined by their buffers were united and aggregated (Fig. 10). Using a suitable tool in ArcGIS SW enables to generalise the shapes in the process without significantly changing the resulting area and its surface shape (Fig. 11).

Step 10: Defining numeric characteristics of the delimited postindustrial landscapes. Apart from localisation and classification characteristics, central planning offices and institutions require numeric data to allow them to estimate e.g. the extent of necessary investments, to assess temporal and transport aspects when providing access to the area, and particularly to define possible problems, assessment criteria and to formulate approaches to possible urbanistic and landscape planning solutions. Such data encompass data on the shape of the given post-industrial landscape, particularly on its area or length (width, radius, and diameter).

Step 11: Visualising of geodata processing results for the whole national territory of the Czech Republic. The original data resolution allows visualising from a large scale 1:25 000 to the small scale 1:2 000000 Examples of visualising show all the 105 PIL identified in the country (Fig. 12) as well as the selection of 44 largest PILs with their typology (Fig. 13).

\section{Results and their Evaluation: SWOT Analysis of Czech Post-Industrial Landscape Iden- tification and Typology Methods}

The primary strength of the outlined solution is the fact that it draws on publicly accessible data both in the Czech Republic and in many EU countries. The procedure is thus repeatable in other areas with analogous result quality. Another advantage is utilisation of GIS technology. Its imple- 
mentation ensures that obtained data will be processed identically in any site and that the quality of results is homogenous throughout the entire studied area. The procedure's simplicity and transparency is also a considerable strength, as it virtually precludes different interpretation of results.

The solution's primary weakness is the use of a unified buffer construction of $500 \mathrm{~m}$ width. Its width as well as its constancy may be subject to discussion, as well as the shape of the resulting areas. The $500 \mathrm{~m}$ buffer width is a result of experiment and undoubtedly represents a compromise outcome of a discussion which focused on both aesthetic and synergetic impact of individual industrial heritage objects on their environment. When solving such an issue at a local level, it would be necessary to take into consideration the impact of all factors which may affect the buffer's width locally and consequently affect the shape of the resulting area, and thus better tailor them to the real conditions of the given area. At the state (national) level,

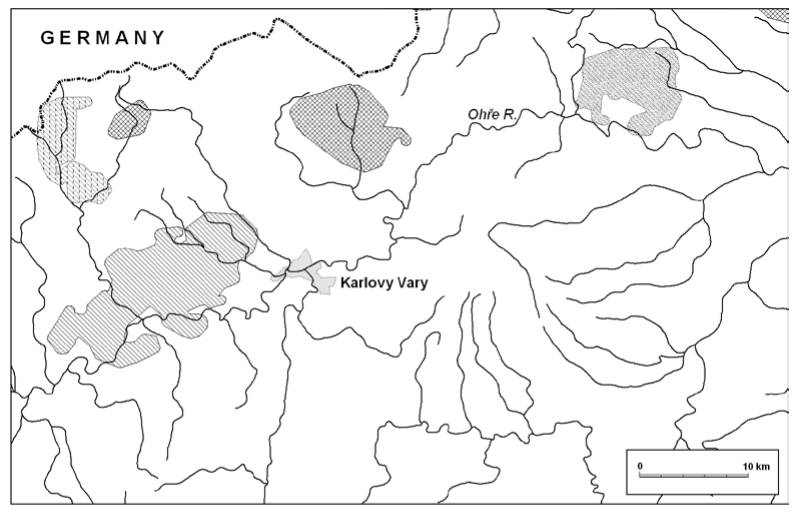

Types of post-industrial landscape:

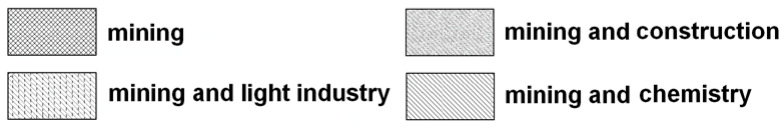

Fig. 11. Simplified outlines of classified post-industrial landscapes identified in Western Bohemia, Czech Republic.

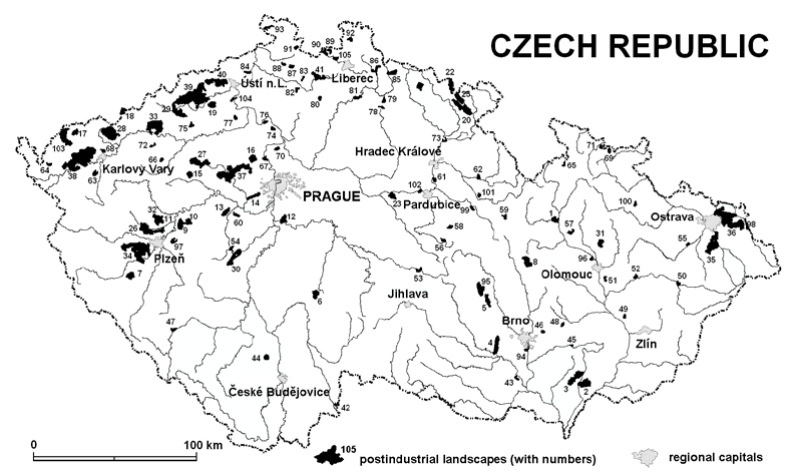

Fig. 12. Post-industrial landscapes (105) identified on the territory of Czech Republic. however, this approach is unrealistic considering the initial stage of post-industrial landscape studies in the Czech Republic, as it involves thousands of objects situated in a similar number of environment types. The above-mentioned results must therefore be viewed as a guide (upon aggregation, different buffer shapes and extents may give rise to partly different areas-conditioned by aggregating/not aggregating smaller sites into larger ones). Generally, it may be supposed that divergences from reality which occur in the process are not likely to be radical, particularly in relation to defining the principal cases-postindustrial landscape areas in the Czech Republic and their utilisation in consequent classification and typology. The selection of criteria for defining post-industrial landscape may be considered another weakness. However, the selection has been conditioned by the available data sets which only partially cover the characteristics of post-industrial landscapes. Considering the standard 


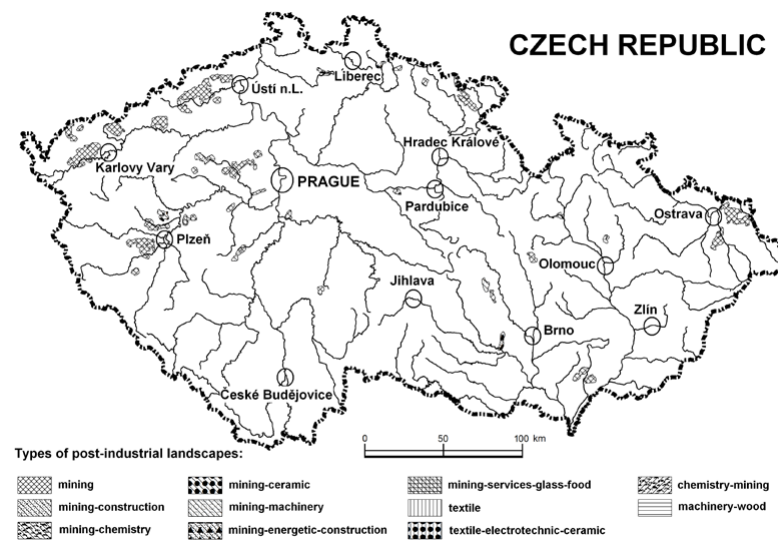

Fig. 13. Classified post-industrial landscapes larger than $10 \mathrm{sq} \mathrm{km}$ as examples.

area concentration of post-industrial landscape features (their synergism and synchronism), it may be supposed that places of significant concentrations of the used characteristics will display high concentrations of most other characteristics, even if reliable data on the latter are not available. Nevertheless, in unusual cases of post-industrial landscapes such an assumption may prove fatal.

Opportunities: the proposed procedure of post-industrial landscape identification and classification may serve as a valuable tool for dealing with similar tasks in countries where similar issues arise and where areas meeting the criteria for being designated as post-industrial landscapes have not been identified and delimited yet. Such countries may have different relevant data available, while other sets of data may be lacking. However, the inspiration how to integrate data of a various topological character presents itself in the proposed solution (point and polygon data layers).

A possible threat may be seen in situations when users with no experience in landscape science, who are experienced in GIS technology, may produce visually attractive map outputs but at the same time be unable to detect errors in their meaning. Results of such uncontrolled mechanic application of the proposed procedure may be misleading and thus undetected errors then might discredit the procedure. Acquired skills in GIS technology implementation cannot replace geographic, geo-ecological or landscape science training and knowledge in any way. Reliability of used databases might be another possible threat. The issue of including industrial, mining and waste deposit areas in the CORINE database which does not distinguish active and fossil units may also be subject to debate (a combination of an industrial area with a brownfield does not necessarily mean that the entire industrial area is a brownfield, and the same applies to mining and waste deposit areas alike), as it also results in a certain degree of overestimating the post-industrial landscape extent. However, modern and operating industrial areas tend to occupy significantly less space than traditional "old" industry. Newly built as well as functional traditional industrial areas, whether converted or "surviving", tend to be less extensive and do not form industrial landscapes. Upon applying a mask for towns of over 50,000 inhabitants and for district towns, a decisive majority of all active industrial sites are localised outside post-industrial landscapes.

\section{Conclusion}

The existence of post-industrial landscapes is a reality of the modern times. First examples of such landscapes appeared at the early stages of the Industrial Revolution, when some businesses did not manage to keep abreast of technological progress. However, since the late 1960s traditional 
industrial countries have been subject to such radical changes in the character and distribution of industrial production that industrial areas and their related transport, and partly also housing zones began to be abandoned en masse. Demilitarisation of industrial societies and transfer of energy, material and labour intensive productions, as well as parts of agricultural production, outside traditional industrial countries to third world countries had similar results. Such massive transfers frequently left behind vast abandoned facilities which gave the surrounding landscapes their distinctive character. Traditional inventory and land use/land cover mapping may respect some of the elements (buildings and facilities) indicating post-industrial landscapes. However, although the existence of post-industrial landscapes is a generally acknowledged fact, no method of territorial delineation for this type of contemporary cultural landscape has been developed. The authors of this paper offer a possible method of inventory and post-industrial landscape mapping. Knowledge of the location, extent, shape, type and other PIL characteristics are relevant for decision-making about such areas' future. The existing government and developer intervention in such areas deal only with some of their aspects, while adoption of holistic approaches is extremely rare. The definition, delimitation, classification and typology of post-industrial landscapes therefore represent a point of departure for the formulation of tasks for the planning, decision-making and administration spheres so that the future of contemporary post-industrial landscapes complied with the sensible requirements of sustainable and progressive development of the human society.

Abstract: The methodology-focused paper outlines definition criteria for post-industrial landscapes. The post-industrial landscape is the legacy of the Industrial Revolution which conditioned the advancement of presently most developed countries of the world. Economic and technological changes, market developments and global division of labour resulted in abandonment of traditional production facilities. The withdrawal of industry had an impact on the settlement structure and suburban farming, demilitarisation of the society took place and social conditions changed. Although post-industrial landscape is a reality in the contemporary world, the methodology aspects of its study have not been given due attention so far. This paper attempts to add to the sum of existing knowledge. It contains description of data sources and procedures of its delimitation presented on the example of the Czech Republic. By implementing GIS tools and publicly accessible data, it identifies and classifies post-industrial landscape areas. The demonstrated procedure's strengths and weaknesses were subjected to SWOT analysis. Considering the availability of similar data in other countries, the same procedure may be implemented on the example of other industrial countries. Delimitation of post-industrial landscape gives the decision makers at various levels a valuable tool important for future decisions in this field.

Acknowledgements

The research results presented in this article were elaborated under the grant project: "The Fate of the Czech Post-Industrial Landscape" No. IAA 300860903 funded by the Grant Agency of the Academy of Sciences of the Czech Republic (for 2009-2011).

\section{References}

Cashen, D. (2007). Redeveloping a North Florida post-industrial landscape, University of Florida. Journal of Undergraduate Research,8(3). URL:http://www.clas.ufl.edu/ jur/200701/papers /paper_cashen.html. 
Conesa, H.M., Schulin, R. \& Nowack B. (2008). Mining landscape: A cultural tourist opportunity or an environmental problem? The study case of the Cartagena-La Unión Mining District (SE Spain). Ecological Economics, 64, 690-700. DOI: 10.1016/j.ecolecon.2007.06.023.

Dulias, R. (2010). Landscape planning in areas of sand extraction in the Silesian Upland, Poland. Landsc. Urban Plann., 95(3), 79-150. DOI: 10.1016/j.landurbplan.2009.12.006.

Dunham-Jones, E., 2007: Economic sustainability in the post-industrial landscape. In K. Tanzer \& R. Longoria (Eds), The Green Braid: Towards an Architecture of Ecology, Economy, and Equity: An ACSA Reader (pp. 44-59). London: Routledge.

Fragner, B. (2005). The post-industrial landscape (Ruhrland-Emscher Park) (in Czech). Vesmír, 84, 178-180.

Gospodini, A. (2006). Portraying, classifying and understanding the emerging landscapes in the post-industrial city. Cities, 23, 311-330. DOI: 10.1016/j.cities.2006.06.002.

Hall, P., 1997: Modelling the post-industrial city. Futures, 29, 311-322. DOI: 10.1016/S0016-3287(97)00013-X.

Hansen, H. \& Winther L. (2006). The heterogenous (post-) industrial landscape of Copenhagen: location dynamics and divisions of labour. In Proceedings of the Sixth European Urban \& Regional Studies Conference (pp. 1-26). $21^{\text {st }}-24^{\text {th }}$ September 2006, Roskilde. URL:http://www.byforskning.dk/publikationer/Siden\%20publikationer/ artikler/Hogni20 Hansen0 LarsWinther.pdf.

Hayes, B. (2006). Infrastructure: A field guide to the industrial landscape. London: W.W. Norton \& Co.

Hillinger, N., Olaru, M. \& Turnock D. (2001). The role of industrial archaeology in conservation: The Resita area of the Roman Carpathians. GeoJournal, 55, 607-630. DOI: 10.1023/A:1021705414938.

Hladnik, D. (2005). Spatial structure of disturbed landscapes in Slovenia. Ecological Engineering, 24, 17-27. DOI: 10.1016/j. ecoleng.2004.12.004.

Hüttl, R.F. (1998). Ecology of post strip-mining landscapes in Lusatia, Germany. Environmental Science and Policy, 1, 129-135. DOI: 10.1016/S1462-9011(98)00014-8.

Keil, A. (2005). Use and perception of post-industrial urban landscapes in the Ruhr. In I. Kowarik \& S. Körner (Eds), Wild Urban Woodlands (pp. 117-130). Berlin-Heidelberg: Springer. DOI: 10.1007/3-540-26859-6_7.

Kirk, J. (2003). Mapping the remains of the postindustrial landscape. Space and Culture, 6, $178-186$. DOI: $10.1177 / 1206331202250100$.

Kirkwood, N. (2001). Manufactured sites: Rethinking the post-industrial landscape. London: Taylor and Francis.

Kolejka, J. (2006). The Rosice-Oslavany Area: The landscape in Helix (in Czech). Životné Prostredie, 40, 187-194.

Kučerjavij, V.P. (1999). Urban ecology. Lviv: Vidavnictvo Svit.Ling, Ch., Handley, J. \& Rodwell J. (2007). Restructuring the post-industrial landscape: A multifunctional approach. Landscape Research, 32, 285-309. DOI: $10.1080 / 01426390701318171$.

Loures, L. (2008). Industrial Heritage: the past in the future of the city. WSEAS Transactions on Environment and Development, 4, 687-696.

Regnerová, T. (2006). Czech brownfields (in Czech). Development News, 8, 6-9.

Rogers, S. (2006). Forgotten Landscapes. Forgotten Landscapes Partnership. URL: www.forgottenlandscapes.org.uk/ FL_ProjectBrief Aug06.doc.

Shahid, Y. \& Nabeshima K. (2005). Japan's Changing industrial landscape. World Bank Policy Research Working Paper, 3758. URL: http://ssrn.com/abstract=844847.

Sklenička, P. \& Charvatová E. (2003). Stand continuity - a useful parameter for ecological network in post-mining landscapes. Ecological Engineering, 20, 287-296. DOI: 10.1016/S0925-8574(03)00053-3.

Slámová, O. (2006). Black Ostrava. The Heart of Europe, 13, 16-19.

Stuczynski, T., Siebielec, G., Korzeniowska-Puculek, R., Koza, P., Pudelko, R., Lopatka, A. \& Kowalik M. (2009). Geographical location and key sensitivity issues of post-industrial regions in Europe. Environ. Monit. Assess., 151,77-91. DOI: 10.1007/s10661-008-0251-4.

Vráblíková, J. \& Vráblík P. (2007). Land use in industrial landscape (in Czech). In K. Střelcová, J. Škvarenina \& M. Blaženec (Eds), Bioclimatology and natural hazards (pp. 1-5). International Scientific Conference, September 17-20, Polana nad Detvou, Slovakia.

Whitehand, J.W.R. \& Morton N.J. (2004). Urban morphology and planning: the case of fringe belts. Cities, 21, 275289. DOI: 10.1016/j.cities.2004.04.001. 